\title{
RESEARCHPAPER
}

\section{Isolation and optimization of lipase producing bacteria from oil contamination soils}

\author{
POONAM SINGH, URVASHI MALVIYA, DHARAMJEET KUMAR, SHUBHAM AWASTHI AND \\ UPASHNA UPADHYAY
}

\begin{abstract}
Department of Molecular and Cellular Engineering, Sam Higginbottom Institute of Agriculture, Technology and Sciences, ALLAHABAD (U.P.) INDIA

Email : drpoonam.singh1@gmail.com
\end{abstract}

Article Info :Received : 24.12.2015; Revised : 13.01.2016; Accepted : 11.02.2016

Lipolytic bacteria were isolated from oil contaminated soil and grown on glycerol tri-butyrate media. The lipase activity is shown by reacting with various chemicals. Lipases are glycerol ester hydrolases that catalyze the hydrolysis of triglycerides to free fatty acids and glycerol. Bacterial lipase producers were isolated from oil spilled soil from vegetable oil processing factories. The effect of incubation time, medium $\mathrm{pH}$, temperature, agitation, inoculums concentration, carbon source and nitrogen source for the lipase production was studied. The lipase production was maximum at $\mathrm{pH}$ 7, temperature by the lipase producing bacteria Staphylococcus. Increased enzymatic production was obtained when the organisms were cultured in medium supplemented with 1per cent protease peptone by Staphylococcus. The results of the present study was to demonstrate that the micro-organism is ideal for extracellular lipase production at industrial level. Different media parameters were optimized for maximal enzyme production. Lipases activity shown on starch containing agar media at $\mathrm{pH}-7.0$ and temperature at $37^{\circ} \mathrm{C}$ for $24-48 \mathrm{~h}$.

Key words : Lipase, Glycerol tributyrate, Extracellular, Oil, Dialysis

How to cite this paper : Singh, Poonam, Malviya, Urvashi, Kumar, Dharamjeet, Awasthi, Shubham and Upadhyay, Upashna (2016). Isolation and optimization of lipase producing bacteria from oil contamination soils. Asian J. Bio. Sci., 11 (1) : $131-135$ [Special Issue of AFBSAH-2016]. 